\title{
Tradition of Sedekah Bumi in Sendang Jomblang Gabus Village: an Ethnography Communication Approach
}

\author{
Fanny Khumalasari ${ }^{1 *}$,Octiva Herry Chandra ${ }^{2}$ \\ ${ }^{1}$ Department of Linguistics, Faculty of Humanities, Diponegoro University, \\ Semarang - Indonesia \\ ${ }^{2}$ Department of Linguistics, Faculty of Humanities, Diponegoro University, \\ Semarang - Indonesia
}

\begin{abstract}
This study aimed to determine the communication patterns formed in the Sendang Jomblang community of Gabus village in conducting Sedekah Bumi. The third communication pattern is more directed in conducting Sedekah Bumi. This research was conducted using descriptive qualitative by describing the results of observations, interviews, and documentation. The method used in this research is the qualitative approach. Based on the results of the analysis of the data, it can be concluded that the communication patterns that are formed are; (1) action communication patterns, (2) interaction communication patterns, and (3) inter-community transaction communication patterns. Groups communication identity is influenced through the personal layer, engagement layer, relational and communal, all of which form a communication identity.
\end{abstract}

\section{Introduction}

Social knowledge was closed relating to everyday human life. For this reason, humans were called social beings because humans cannot live alone. There needed for communication to survive as a social being. The definition of communication was the process of delivering messages from communicators to communicants through certain media produce effect/goals by expecting feedback.

Communication is a tool used by society to interact with other people. Both oral and written communication have an interaction process. It was undeniable that most of the human person formed as a result of social interactions with others in groups or society.

Communication was part of human life because people communicated with each other in the interactions of life. There was 3 part that needed be realized that the role of communication was very necessary for social life, even in the teaching and learning process, because the teaching and learning process was essentially a communication process.

\footnotetext{
* Corresponding author: khumalasarifanny@gmail.com
} 
Good communication was needed to connect with other people. Communication can only occur when using the same sign system. Interpersonal communication would often occur in shaping a person's character. According to Verdeber (1986) in Rahkmat (2007), interpersonal communication was a process of interaction and sharing of meaning which contained ideas and feelings. Interpersonal communication carried out in the family aimed to strengthen social relationships.

The communication pattern is defined as a form of relationship between two or more people. Those were a process of sending and receiving a message which related to the question that can be understood "(Djamarah, 2004:1). The dimensions of the communication pattern consisted of two types, namely, a concept-oriented pattern and a socially oriented pattern that has different relationship directions (Sumarto, 2006:1). Tubbs and Moss said that the pattern of communication or relationship could be characterized by: complementary or symmetrical.

On social communication, there was a social culture that happened in the community. One of the cultures was called tradition. The tradition was society activities that were done by people from their ancestors. According to Kartodirjo (1990), the tradition contained in Javanese society was a strong attitude. Even though there was a process of development and modernization continue of the tradition still continued. Javanese people were indeed appreciated their culture strongly. Even though they have been exposed to modernization, the generation still carried out the traditions of their ancestors that existed from ancient times.

One of the Javanese traditions that still existed until now was carried out. It has become a routine for the Javanese people every year was Sedekah Bumi. Sedekah Bumi was a form of local wisdom in the form of ceremonies traditions as a form of communication between humans and nature (Wibowo et al., in Slamet et al., 2015"47).

Sedekah Bumi tradition was carried out once a year in the "apit" month called big harvest. Sedekah Bumi is a ritual by the people of Gabus village, which mean giving charity to the earth or the intention to give nature for the welfare of the earth. The villagers dis this because they still believe in the benefits of implementing traditions that have existed since time immemorial. So until now, the people of the village of Gabus were still preserved.

In line with the existing facts of the Sedekah Bumi ceremony. It has been preserved until nowadays, there contained in series of events. This means as part of gratitude to God. Based on the background of the problem above, the researcher is interested in writing research entitled "Tradition of Sedekah Bumi in Sendang Jomblang, Gabus Village: An Ethnography of Communication Approach".

\section{Literature Review}

\subsection{Previous Study}

The first research was written by (Muslimin and Jannah, 2018), entitled "The Study of Analysis of Interpersonal Communication Patterns in the Film Heaven that Kunts Agus 2015". This article was published in the An-Nida Journal. The result of this study was that the communication that was used between the players in "Heaven that is not Missed" was dyadic communication (communication of two people), which took place in primary and secondary. The second research has done by (Nurjaman 2016) entitled "Kyai Communication Patterns in Maintaining Solidarity". This article was published in the Journal of Academic Journal for Homiletic Studies. From the results of the analysis of the data, it concluded that the communication patterns of the kyai in maintaining the solidarity of the Jamaah were: (1) The communication action, (2) The interaction communication, and (3) The transaction 
communication. The communication identity of kyai was influenced through the personal, engagement, relational, and communal; all forms were a communication identity.

The third research is written by (siswesa etc.,2020) entitled "The Value of Islamic Education in Sedekah Bumi: Studies in Melati Hamlet, Olak-Olak Kubu Village, kudu Raya". It was published in the article Journal of Research and Thought of Islamic Education. The results of the research showed that the traditions of Sedekah Bumi to the earth as a form of gratitude to Allah SWT was carried out in a series of clean the village, salvation, and social activities. The value of Islamic education that found in the tradition of the earth giving in Melati Hamlet, Olak-Olak Kubu Village, Kubu Raya Regency was the value of gratitude, friendship, al-Ukhuwah, Insyirah and Al-Munfiqun, earth, and mutual cooperation.

The fourth research was written by (Wijayanti and Puspitasari, 2018) entitled:" The Analysis of Intercultural Communication Patterns of Santri at the Tahfidz Daarul Quran Islamic Boarding School in Central Jawa". This article was published in the journal Paramasastra Unesa. Based on the results of observations and directed communication patterns. Symbolic communication patterns consist of verbal communication patterns in the form of language used by the students. It was in the boarding school environment and nonverbal communication patterns. It was in the form of behaviour and expression when interacting with fellow students. This happened directly so that it caused feedback from the communicator to the communicate.

The fifth research has done by (Sari et al., 2010) entitled "The Effect of Family Communication Patterns in the Family Socialization Function on Child Development". This journal was published in the Journal of Development Communication. This research explained that the family communications pattern analysis, function of socialization of family, form of communication happened at the family who live in settlements and countrified in Bekasi City. Besides, also to know the development of the child of the family.

Moreover, the last, the sixth research is written by (Arinda, 2014) entitled "Sedekah Bumi as a Convection of the Javanese Tradition of the Strarurejo Society". The results showed that Nyadran was implemented after the Straturejo community harvested their crops simultaneously.

\subsection{Colour illustrations}

You are free to use colour illustrations for the online version of the proceedings. However, any print version will be printed in black and white unless special arrangements have been made with the conference organiser. Please check whether or not this is the case. If the print version is black and white only, you should check your figure captions carefully and remove any reference to colour in the illustration and text. In addition, some colour figures will degrade or suffer a loss of information when converted to black and white, and this should be considered when preparing them.

\section{Theory framework}

\subsection{Communication}


Communication was necessary for every human being to interact in everyday life, so communication became human's everyday clothes (Muhtadi, 2012: 14). According to Onong Uchjana Effendy in the book "Communication Science" in Theory and Practice. "The term communication in English "Communications" comes from the Latin word "Communicatio" and comes from the word "Communis", which mean "same", meaning the same meaning. The similarity of meaning here is about something communicated, because communication will take place as long as there is a similarity in meaning about what was said or communicated. A conversation is said to be communicative when both parties, namely the communicator and the communicant, understand the language of the message being conveyed "(Effendy, 2005:9) as quoted by Onong Uchjana Effendy in the book Communication science in Carl's Theory and Practice. Hovland, defined 'Communication is a systematic effort to formulate firmly the principles of delivering information and forming opinions and attitudes" (Effendy, 2005:10). Meanwhile, according to Gode (1965: 5) quoted Wiryanto $(2-4: 6)$, the definition of communication is "it is a process that makes common to or several what the monopoly of one or some more that was originally a monopoly by one or several people".

The essence of communication was understanding communication means understanding what happened during communication, what happened, what are the benefits, what consequences it causes.

\subsection{Sedekah Bumi}

The The implementation of Sedekah Bumi on the earth (Nyadran) by the community was to remember their departed ancestors and ancestral services in their efforts to clear land, which has been occupied by the community to build houses and look for life. This honour in the earth alms procession (Nyadran) is carried out by bringing various kinds of products to the place near the ancestral burial. In addition, the community also carries out grave pilgrimages and recitations of prayers together for ancestors who have passed away.

Sedekah Bumi, which were often given the name (Nyadaran), is a culture that has become a community tradition. The implementation of the Sedekah Bumi (Nyadran) also instructed the public to follow the implementation of the Sedekah Bumi well and orderly until it was finished. As the community's respect for the ancestors who have passed away, the leader leads a prayer together for the deceased ancestors at the grave. The graves of the ancestors that were famous and frequently visited in the implementation of the Sedekah Bumi were the tombs of "Mbah Mursodo" and "Mbah Mursa'id". The leader of the village (kepala adat) also gave rituals such as pouring water on the graves of their ancestors, sowing flowers and fragrances of "incense", placing chicken eggs, then reciting prayers again.

After praying together, several community leaders gave remarks as well as explained the purpose of the implementation of the Sedekah Bumi (Nyadran). After that, all the people who participated in the Sedekah Bumi procession (Nyadran) ate together at that place. There were about ten "among" placed in a "tampah" or food container made of knitted bamboo. All people seem to be in harmony with each other, so that community by the community as food that contains a lot of blessings from Allah SWT (God).

\subsection{The Essence of Communication}

Understanding communication means understanding what happened during communication, why it happened, what benefits are felt, what consequences it caused, 
whether the purpose of communicating activities is what is desired, understanding things that can affect and maximize results of the incident.

According to Anwar Arifin (1988: 17), communication was a multi-meaning concept. The meaning of communication can be differentiated based on:

Communication as a social process Communication on this meaning exists in the context of social science, where social science experts conduct research using a communication approach that generally focuses on human activities and the relationship between messages and behaviour.

\section{Methodology}

This research was a descriptive qualitative study because the data showed in a description. The researcher described what has been observed, interviewed and documentation. The descriptive research recorded carefully and carefully data in the form of words, sentences, discourses, and does not use numbers. The data obtained by the researcher were first complied, explained, then analyzed.

\subsection{Research Object}

The research on this research was people community in the village Gabus.

\subsection{Data Collection}

The data in this study were the form of speeches by the community of the village of Gabus regarding communication patterns. The first method in this research was descriptive qualitative. This research used triangulation which used a questioner, interview, and documentation.

\subsection{Analysis Data}

In this research, the data analysis method used is descriptive qualitative. According to Bogdan and Biklen (in Moleong, 2006: 248) stated that qualitative data analysis was an effort made by working with data, organizing data, sorting it into manageable units, synthesizing it, looking for and finding patterns, finding what is important and what to learn, and decide what to tell others.

The data analysis technique used in this research was qualitative data analysis (Kriayanto, 2006:192) which began the analysis of various data that researchers have collected in the field. The data was both from literature study and field research. To determine the validity of the data, several inspection techniques are needed, which are adapted to the form of qualitative research. As for what is included in the scope of testing, the validity of the data in this study is as follows: (1) Extension of Observations; (2) Triangulation. Triangulation, namely observation, documentation, and interviews.

The steps taken at the final stage include: (1) processing and analyzing research data; (2) drawing conclusions based on data analysis; (3) compiling a research report.

\section{Result and Discussion}

Based on the data obtained from observations and interviews with several informants, it is known that the earth alms are carried out by the people of Sendang Jomblang, Gabus Village. Sedekah Bumi was carried out once a year. Sedekah Bumi was a culture. The diverse 
islands in Indonesia made Indonesia rich in culture. Sedekah Bumi Ceremony was one of the traditions which became Indonesia has a very diverse culture. Sedekah Bumi was a culture belonging to the Javanese tradition.

On the other hand, it is known that the Sedekah Bumi that was carried out by the people of Sendang Jomblang, Gabus Village, Purwodadi Regency has its uniqueness and characteristics. Sedekah Bumi tradition was carried out once a year in the "apit" month or called big harvest. Sedekah Bumi was a ritual usually carried out by the people of Gabus village, which meant giving charity to the earth or the intention to give Sedekah Bumi for the earth's welfare. The villagers do this because they still believe in the implementing traditions that have existed since ancient times. So until now, the people of the village of Gabus were still preserving it.

Sedekah Bumi tradition was still being carried out because, with the continuation of traditions, the culture can be recognized by the wider community. In its communication undertaken by the community through the Sedekah Bumi. The interaction was one of the factors that shaped the communicator to talk to each other.

This activity was carried out by the community so that the communication patterns formed are the community's communication patterns. Communication was carried out directly face to face in the same place and can see each other. It can even respond immediately when the communication takes place, including communication, which was an essential part of building individual and community social relationships.

\subsection{Communication Pattern}

According to the observations above, the results of the analysis of the data, it can be concluded that the communication patterns that were formed, namely; (1) action communication patterns, (2) interaction communication patterns, and (3) inter-community transaction communication patterns.

\subsection{The Way of Communication}

The way the communication patterns appeared from the Sedekah Bumi tradition was the leaders of Gabus village leads to pray together. The community followed how the leaders prayed for the nature. The communication between the leader (kepala adat) with the community were the way of the ceremony done to success Sedekah Bumi.

\subsection{The Communication Topic during the Ceremony}

These was the thing that the Sedekah Bumi was talking during the ceremony. The activities carried out by local residents when doing Sedekah Bumi are as follows:

- $\quad$ Residents bring fruit cone, rice cone and ingkung (chicken)

- Gather in Jomblang with a "blessing"

- Remarks from hamlet heads and village heads using krama (Javanese) language usually discussing taxes and village government activities (building markets, building roads, irrigation canals, and increasing additional staple food for babies)

- $\quad$ Pray together led by traditional leaders or leaders (kepala adat)

- Eat "blessing" together

- Take the water in the Sendang to drink/take home

- The rest of the rice, chicken head, and claws that are brought by farmers usually wrap it together in one teak leaf and put in the corner of each rice field (offering for repelling logs/sfateu) so that the plants were fertile 
All those activities were led by the leaders or we called it (kepala adat) for the ceremony. From the community were asked to bring the fruit cone, rice cone and ingkung (chicken). They gathered together to bless (grateful) what they have had right now. Then, they communicated for praying together. Those activities above were what they communicated during the ceremony of Sedekah Bumi.

The intensity of communication was very influential on the communication patterns that were formed in this community. This event was held every Friday legi (calender on Javanese time), once a year (harvest seadon). There was a water source there. The water source was used for rice fields, and drinking ate during the water. When washing your face, pray to each one for your safety. Wash his face using coconut bathok (tool made from coconut shell) for the dipper. This was done before the celebration began. After doing this, all the residents sat on their knees near the water source and waited for a signal from their customary leader. After receiving a signal from their traditional leader, they ate together using teak leaves arranged by local women. All residents bring their food contained (jadah, mendhut, rice, grilled chicken).

In conducting this traditional ceremony, it was led by the traditional leader. Here a communication pattern was formed between the customary leader and the community. However, domination still showed the communication pattern of society. Because the customary head only communicated when he wanted to carry out the ceremony.

\section{Conclusion}

In In general, it concluded that the Sedekah Bumi tradition was well preserved because it has been passed down from generation to generation by the people of Sendang Jomblang, Gabus Village. Apart from the culture, the Javanese vies of life have made the Sedekah Bumi traditions still preserved. Javanese people believe in important events to achieve the goal rooted in values so that the ancestral heritage is preserved.

Based on the results of the analysis of field data, namely, the communication pattern of the Gabus Village community in conducting Sedekah Bumi was a communication pattern formed by the community. Interaction Communication Patterns and Transaction Communication Pattern. This Communication pattern was carried out in the form of group communication. Group communication took place between the community and several small or large groups, and it was difficult for interpersonal communication to occur in group communication, such as in the earth alms process that was carried out.

\section{References}

[1] Anonim, 2006. Kamus Besar Bahasa Indonesia. Edisi Ketiga, jakarta: Balai Pustaka

[2] Anggun Sisweda, S. R. (2020). Nilai Pendidikan Islam pada Tradisi Sedekah Bumi. JRTIE: Journal of Research and Thought of Islamic Education.

[3] Atrianing Yessi Wijayanti, N. P. (2018). Analisis Pola Komunikasi Antar Budaya Para Santri. PARAMASASTRA.

[4] Bungin, Burhan, 2006. Sosiologi Komunikasi: Teori, Paradigma, dan Diskursus Morissan, 2013.

[5] Teori Komunikasi Individu Hingga Massa. KDT. Jakarta.

[6] Cangara, Hafied., 2006. Pengantar Ilmu Komunikasi. Jakarta: PT. Raja Grafindo Persada.

[7] DeVito JA. 1997. Komunikasi Antar Manusia. Indonesia Professional Books, Jakarta. 
[8] Khoirul Muslimin, L. A. (2018). Studi Analisis Pola Komunikasi Interpersonal dalam film Surga yang Tak Dirindukan. Jurnal An-Nida.

[9] Nurjaman, A. (2016). Pola Komunikasi Kyai dalam Memelihara Solidaritas. Ilmu Dakwah: Academic Journal for Homiletic Studies.

[10]R., I. Y. (2014). SEDEKAH BUMI (NYADRAN) SEBAGAI KONVENSI TRADISI JAWA DAN ISLAM MASYARAKAT SRATUREJO BOJONEGORO. el Harakah.

[11] Sentosa, A. T. (2015). Pola Komunikasi dalam Proses Interaksi Sosial di Pndok Pesantren Nurul Islam Samarinda. e-journal Ilmu Komunikasi.

[12] Widodo AM 2009. "Pengaruh Komunikasi Keluarga Terhadap Pencegahan Remaja dalam

[13] Menyimpan Gambar Porno di Handphone" (tesis) Unitomo, Surabaya 